\title{
Gangguan Kepadatan Tulang pada Orang Dewasa di Daerah Urban dan Rural
}

\author{
Bone Density Disorders in Adults in Urban and Rural Areas
}

\author{
Sarah Mardiyah, Ratu Ayu Dewi Sartika
}

\author{
Departemen Gizi Fakultas Kesehatan Masyarakat Universitas Indonesia
}

\begin{abstract}
Abstrak
Gangguan kepadatan tulang atau osteoporosis dan osteopenia merupakan masalah kesehatan masyarakat utama yang disebabkan oleh banyak faktor. Tujuan dari penelitian ini adalah mengetahui berbagai faktor yang berhubungan dengan gangguan kepadatan tulang pada kelompok usia dewasa di daerah urban dan rural terpilih di Provinsi Jawa Barat tahun 2012. Desain penelitian yang digunakan adalah potong lintang dengan sampel 142 responden. Penelitian dilakukan pada bulan Mei - Juni 2012 di Pesona Khayangan, Kecamatan Sukmajaya, Kota Depok, sebagai daerah urban dan Desa Pabuaran, Kecamatan Gunung Sindur, Kabupaten Bogor sebagai daerah rural. Prevalensi gangguan kepadatan tulang dalam penelitian ini adalah sekitar $31,7 \%$ (4,2\% osteoporosis dan $27,5 \%$ osteopenia). Analisis multivariat menemukan responden yang mempunyai indeks massa tubuh (IMT) $<23,49 \mathrm{~kg} / \mathrm{m}^{2}$ berisiko mengalami gangguan kepadatan tulang 5,5 kali lebih tinggi daripada responden dengan IMT > 27,36 kg/m². Responden yang mempunyai IMT 23,49 $-27,36 \mathrm{~kg} / \mathrm{m}^{2}$ berisiko mengalami gangguan kepadatan tulang 2,2 kali lebih tinggi daripada responden yang mempunyai IMT > 27,36 kg/m² setelah dikontrol variabel usia, asupan vita$\min \mathrm{D}$, dan asupan protein. Pada penelitian ini, IMT merupakan faktor yang paling berhubungan dengan gangguan kepadatan tulang setelah dikontrol variabel usia, asupan vitamin D, dan asupan protein. Semakin rendah IMT,maka semakin tinggi risiko gangguan kepadatan tulang.

Kata kunci: Gangguan kepadatan tulang, indeks massa tubuh, osteopenia, osteoporosis
\end{abstract}

\footnotetext{
Abstract

Bone density disorder (osteoporosis and osteopenia) is a major public health problem caused by multifactor. The purpose of this study was to find out factors related to adult bone density disorder in the selected urban and rural area, West Java Province, 2012. It used cross-sectional method and the samples were 142 respondents. The data was taken from 2012 May to June in Pesona Khayangan, Kecamatan Sukmajaya, Kota Depok as the ur-
}

ban area and Desa Pabuaran, Kecamatan Gunung Sindur, Kabupaten Bogor as the rural area. Prevalence of bone density disorder in this study was $31.7 \%$ (4.2\% osteoporosis and $27.5 \%$ osteopenia). Multivariate analysis verified that respondent with body mass index $(\mathrm{BMI})<23.49 \mathrm{~kg} / \mathrm{m}^{2}$ will 5.5 times higher to have bone density disorder than respondent with $\mathrm{BMI}>$ $27.36 \mathrm{~kg} / \mathrm{m}^{2}$. Respondent with BMI $23.49-27.36 \mathrm{~kg} / \mathrm{m}^{2}$ will 2.2 times higher to have bone density disorder than respondent with $\mathrm{BMI}>27.36 \mathrm{~kg} / \mathrm{m}^{2}$ after controlled by age, vitamin $\mathrm{D}$ and protein intake variable. In this study, $\mathrm{BMI}$ is the most related factor of bone density disorder after controlled by age, vitamin D and protein intake variable. The lower BMI, the higher risk of bone density disorder.

Keywords: Bone density disorder, body mass index, osteopenia, osteoporosis

\section{Pendahuluan}

Gangguan kepadatan tulang (osteoporosis dan osteopenia) saat ini menjadi masalah kesehatan masyarakat utama yang diderita jutaan orang di seluruh dunia. Osteoporosis adalah suatu penyakit yang dicirikan oleh massa tulang yang rendah dan kemerosotan mikroarsitektur jaringan tulang sehingga menyebabkan peningkatan kerapuhan dan risiko patah tulang. ${ }^{1}$ Sebelum terjadi osteoporosis, seseorang terlebih dahulu mengalami osteopenia, kehilangan sejumlah massa tulang akibat berbagai keadaan. Kedua gangguan kepadatan tulang ini sering muncul tanpa disertai gejala yang nyata dan baru disadari setelah terjadi fraktur, atau yang dikenal sebagai the silent disease. ${ }^{2}$ Gangguan kepadatan tulang (osteo-

Alamat Korespondensi: Sarah Mardiyah, Departemen Gizi Fakultas Kesehatan Masyarakat Universitas Indonesia, Gd. F Lt. 2 Kampus Baru UI Depok 16424, Hp.085697711592,e-mail: sarahmardiyah@gmail.com 
porosis dan osteopenia) merupakan penyakit dengan etiologi multifaktorial antara lain usia, jenis kelamin, gaya hidup, asupan zat gizi. Suatu penelitian pada tahun 2010 melaporkan proporsi risiko osteoporosis di Provinsi Jawa Barat mencapai 22,2\% dan risiko osteopenia $34,6 \%$. Angka ini masih lebih tinggi dibandingkan dengan proporsi risiko osteoporosis di Yogyakarta yang hanya sekitar $17,1 \%$ dan osteopenia $26,7 \% .^{3}$

Penelitian ini mempelajari berbagai faktor yang berhubungan dengan gangguan kepadatan tulang. Mengingat informasi tersebut masih terbatas, khususnya untuk Provinsi Jawa Barat yang merupakan provinsi padat penduduk dengan proporsi risiko osteoporosis dan osteopenia yang cukup tinggi. Ketersediaan informasi tentang besaran masalah dan pengetahuan tentang faktor-faktor yang berhubungan dengan gangguan kepadatan tulang dapat menjadi bahan pertimbangan upaya promotif dan preventif.

\section{Metode}

Penelitian dengan desain potong lintang ini menggunakan data sekunder dari penelitian "Pengaruh Asupan Asam Lemak Trans di Daerah Rural dan Urban serta Hubungan dengan Kejadian Dislipidemia”. Penelitian ini dilakukan di daerah urban, Pesona Khayangan, Kecamatan Sukmajaya, Kota Depok dan daerah rural Desa Pabuaran, Kecamatan Gunung Sindur, Kabupaten Bogor terpilih di Provinsi Jawa Barat. Kriteria inklusi sampel adalah laki-laki dan perempuan usia dewasa (30 - 55 tahun) yang bersedia diwawancara. Kriteria eksklusi adalah responden yang menderita penyakit berat, tidak dapat berdiri tegak akibat menderita penyakit, kecelakaan atau kondisi kesehatan lain dan wanita hamil. Pengambilan sampel dilakukan dengan mendaftar warga usia dewasa (30 - 55 tahun) pria dan wanita yang tinggal di lokasi terpilih. Dua hari sebelum waktu pengambilan data, undangan diberikan kepada warga. Sampel sebanyak 142 orang diambil berdasarkan purposive sampling.

Instrumen dalam penelitian ini antara lain kuesioner untuk mengumpulkan data karakteristik yang meliputi usia, jenis kelamin, wilayah tempat tinggal, pendidikan, pengetahuan, dan gaya hidup yang meliputi aktivitas olahraga, merokok. Food Frequency Questionnaire (FFQ) digunakan untuk mengumpulkan data konsumsi minuman penghambat penyerapan kalsium meliputi kopi, teh, soft drink, food recall 1 x 24 jam untuk mengumpulkan data asupan zat gizi meliputi kalsium, vitamin $\mathrm{D}$, fosfor, protein, timbangan digital dengan ketelitian $0,1 \mathrm{~kg}$ untuk mengukur berat badan, microtoice dengan ketelitian $0,1 \mathrm{~cm}$ untuk mengukur tinggi badan, dan densitometer tulang. Achilles express/insight metode quantitative ultrasound dengan sensitivitas 97\% untuk mengukur Densitas Mineral Tulang (DMT). Nilai T di- nyatakan dengan angka simpangan baku dengan ketelitian 1 desimal. Densitas mineral tulang (DMT) dinyatakan normal jika T-score $>-1,0 \mathrm{SD}$, osteopenia jika T-score -1,0 s.d. $-2,5 \mathrm{SD}$ dan osteoporosis jika T-score $\leq-2,5 \mathrm{SD}$. Berdasarkan hasil pengukuran DMT, diketahui $69,1 \%$ responden mempunyai DMT normal, 26,2\% osteopenia dan $4,7 \%$ osteoporosis.

\section{Hasil}

Sebagian besar responden yang berusia $<50$ tahun $(81,7 \%)$ jauh lebih tinggi daripada yang berusia $\geq 50$ tahun $(18,3 \%)$. Mayoritas responden berjenis kelamin wanita $(67,6 \%)$ dan lebih banyak yang bermukim di wilayah rural $(69,0 \%)$. Proporsi responden yang tidak sekolah/tidak tamat SD adalah sekitar $27,5 \%$, tamat SD $(29,6 \%)$, SMP $(6,3 \%)$, SMA dan akademi/perguruan tinggi masing-masing $18,3 \%$. Responden dengan tingkat pengetahuan kurang yang ditemukan sekitar 57,7\% relatif lebih tinggi daripada yang dengan tingkat pengetahuan baik $(42,3 \%)$.

Responden yang tidak melakukan aktivitas olahraga $(67,6 \%)$ lebih banyak daripada yang melakukan aktivitas olahraga $(32,4 \%)$. Sebagian besar responden bukan perokok $(75,4 \%), 21,1 \%$ perokok dan $3,5 \%$ pernah merokok. Sekitar 53,5\% responden mempunyai kebiasaan konsumsi minuman penghambat penyerapan kalsium $\geq$ median, dan $46,5 \%$ sisanya $<$ median.

Hanya sekitar $6,3 \%$ responden yang mempunyai asupan kalsium cukup, sebagian besar $(93,7 \%)$ asupan kalsium kurang. Rata-rata asupan kalsium responden $276,99 \mathrm{mg}$ dengan standar deviasi $182,47 \mathrm{mg}$, terendah $19,3 \mathrm{mg}$, dan tertinggi $837,1 \mathrm{mg}$. Responden dengan asupan vitamin D cukup sekitar $28,9 \%, 71,1 \%$ sisanya asupan vitamin D kurang. Rata-rata asupan vitamin D responden 3,62 $\mu \mathrm{g}$ dengan standar deviasi 3,62 $\mu \mathrm{g}$, terendah tidak mengonsumsi sama sekali $(0,0 \mu \mathrm{g})$ dan tertinggi 15,3 $\mu \mathrm{g}$. Sebagian besar responden dengan asupan fosfor cukup (70,4\%), yang kurang hanya $29,6 \%$. Ratarata asupan fosfor $652,44 \mathrm{mg}$ dengan standar deviasi $258,81 \mathrm{mg}$, asupan terendah $182,0 \mathrm{mg}$ dan tertinggi $1367,8 \mathrm{mg}$. Responden dengan asupan protein cukup $(56,3 \%)$ lebih besar daripada asupan protein kurang $(43,7 \%)$. Rata-rata asupan protein responden 49,49 gram dengan standar deviasi 22,01 gram, terendah 13,1 gram dan tertinggi sekitar 136,7 gram. Responden yang mempunyai IMT kurang $\left(<18,5 \mathrm{~kg} / \mathrm{m}^{2}\right)$ sebesar $4,2 \%$, kategori normal $\left(18,5-24,9 \mathrm{~kg} / \mathrm{m}^{2}\right)$ sekitar $39,4 \%$, IMT lebih $\left(25,0-27,0 \mathrm{~kg} / \mathrm{m}^{2}\right)$ sekitar $18,3 \%$, dan obesitas (> $27,0 \mathrm{~kg} / \mathrm{m}^{2}$ ) sekitar $38,0 \%$ (Tabel 1).

Ditemukan hubungan yang signifikan antara usia dengan gangguan kepadatan tulang (nilai $\mathrm{p}<0,05$ ). Responden yang berusia $\geq 50$ tahun berisiko 2,6 kali lebih besar untuk mengalami gangguan kepadatan tulang daripada yang berusia $<50$ tahun. Tidak ada hubungan yang 
signifikan antara jenis kelamin dengan gangguan kepadatan tulang (nilai $\mathrm{p}>0,05$ ). Responden yang mengalami gangguan kepadatan tulang (osteoporosis dan osteopenia) lebih banyak yang bermukim di wilayah urban $(34,1 \%)$ daripada di wilayah rural $(30,6 \%)$. Namun, secara statistik, tidak ada hubungan yang signifikan antara wilayah tempat tinggal dengan gangguan kepadatan tulang (nilai $\mathrm{p}>0,05$ ).

Responden yeng mengalami gangguan kepadatan tulang lebih banyak yang berpendidikan rendah $(32,2 \%)$ daripada berpendidikan tinggi $(30,8 \%)$, tetapi secara statistik tingkat pendidikan tidak berhubungan bermakna dengan gangguan kepadatan tulang (nilai $p>0,05$ ). Proporsi responden yang tergolong gangguan kepadatan tulang lebih banyak yang mempunyai tingkat pengetahuan kurang $(34,1 \%)$ daripada tingkat pengetahuan baik $(28,3 \%)$, tetapi tidak berhubungan bermakna dengan gangguan kepadatan tulang (nilai $p>0,05$ ) (Tabel 2).

Responden yang mengalami gangguan kepadatan tulang lebih banyak yang tidak berolahraga $(32,3 \%)$ dibandingkan dengan yang berolahraga $(30,4 \%)$, tetapi secara statistik hubungan aktivitas olahraga dengan gangguan kepadatan tulang tidak bermakna (nilai $\mathrm{p}>0,05$ ). Responden yang mengalami gangguan kepadatan tulang lebih banyak yang perokok $(33,3 \%)$ daripada yang dulu perokok dan bukan perokok $(31,3 \%)$, tetapi hubungan kebiasaan merokok dengan gangguan kepadatan tulang secara statistik tidak bermakna (nilai $p>0,05$ ). Kebiasaan konsumsi minuman penghambat penyerapan kalsium tidak berhubungan bermakna dengan gangguan kepadatan tulang (nilai $\mathrm{p}>0,05$ ) (Tabel 3).

Asupan kalsium tidak berhubungan bermakna dengan gangguan kepadatan tulang (nilai $\mathrm{p}>0,05$ ). Responden yang mengalami gangguan kepadatan tulang lebih banyak yang mengalami asupan vitamin D kurang $(35,6 \%)$ daripada yang asupan vitamin D cukup $(22,0 \%)$. Namun, tidak ditemukan hubungan yang signifikan antara asupan vitamin D dengan gangguan kepadatan tu- lang (nilai $\mathrm{p}>0,05$ ). Asupan fosfor dan protein juga tidak berhubungan bermakna dengan gangguan kepadatan tulang (nilai $\mathrm{p}>0,05$ ) (Tabel 4).

Untuk analisis IMT responden, dikelompokkan menjadi tiga kategori berdasarkan nilai persentil. Proporsi

Tabel 1. Distribusi Variabel Penelitian

\begin{tabular}{|c|c|c|c|}
\hline Variabel & Kategori & $\mathbf{n}$ & $\%$ \\
\hline \multirow[t]{3}{*}{ Densitas mineral tulang } & Osteoporosis & 6 & 4,2 \\
\hline & Osteopenia & 39 & 27,5 \\
\hline & Normal & 97 & 68,3 \\
\hline \multicolumn{4}{|l|}{ Karakteristik responden } \\
\hline \multirow[t]{2}{*}{ Usia (tahun) } & $\geq 50$ & 26 & 18,3 \\
\hline & $<50$ & 116 & 81,7 \\
\hline \multirow[t]{2}{*}{ Jenis kelamin } & Wanita & 96 & 67,6 \\
\hline & Pria & 46 & 32,4 \\
\hline \multirow[t]{2}{*}{ Tempat tinggal } & Urban & 44 & 31,0 \\
\hline & Rural & 98 & 69,0 \\
\hline \multirow[t]{5}{*}{ Tingkat pendidikan } & $<\mathrm{SD}$ & 39 & 27,5 \\
\hline & $\mathrm{SD}$ & 42 & 29,6 \\
\hline & SMP & 9 & 6,3 \\
\hline & SMA & 26 & 18,3 \\
\hline & Akademi/perguruan tinggi & 26 & 18,3 \\
\hline \multirow[t]{2}{*}{ Tingkat pengetahuan } & Kurang & 82 & 57,7 \\
\hline & Baik & 60 & 42,3 \\
\hline \multicolumn{4}{|l|}{ Gaya hidup } \\
\hline \multirow{2}{*}{ Aktivitas olahraga } & Tidak & 96 & 67,6 \\
\hline & Ya & 46 & 32,4 \\
\hline \multirow[t]{3}{*}{ Kebiasaan merokok } & Perokok & 30 & 21,1 \\
\hline & Pernah merokok & 5 & 3,5 \\
\hline & Bukan perokok & 107 & 75,4 \\
\hline \multicolumn{4}{|l|}{ Kebiasaan konsumsi minuman } \\
\hline \multirow[t]{2}{*}{ Penghambat penyerapan kalsium } & $\geq$ median $(2,0)$ & 76 & 53,5 \\
\hline & $<\operatorname{median}(2,0)$ & 66 & 46,5 \\
\hline \multicolumn{4}{|l|}{ Asupan zat gizi } \\
\hline \multirow[t]{2}{*}{ Kalsium } & Kurang & 133 & 93,7 \\
\hline & Cukup & 9 & 6,3 \\
\hline \multirow[t]{2}{*}{ Vitamin D } & Kurang & 101 & 71,1 \\
\hline & Cukup & 41 & 28,9 \\
\hline \multirow[t]{2}{*}{ Fosfor } & Kurang & 42 & 29,6 \\
\hline & Cukup & 100 & 70,4 \\
\hline \multirow{2}{*}{ Protein } & Kurang & 62 & 43,7 \\
\hline & Cukup & 80 & 56,3 \\
\hline \multirow[t]{4}{*}{ Indeks massa tubuh } & Kurang & 6 & 4,2 \\
\hline & Normal & 56 & 39,4 \\
\hline & Lebih & 26 & 18,3 \\
\hline & Obesitas & 54 & 38,0 \\
\hline
\end{tabular}

Tabel 2. Karakteristik Responden dengan Gangguan Kepadatan Tulang

\begin{tabular}{|c|c|c|c|c|c|c|c|c|}
\hline \multirow{3}{*}{ Variabel } & \multirow{3}{*}{ Kategori } & \multicolumn{4}{|c|}{ Gangguan Kepadatan Tulang } & \multirow{3}{*}{ Nilai p } & \multirow{3}{*}{ OR } & \multirow{3}{*}{ 95\% CI } \\
\hline & & \multicolumn{2}{|c|}{ Osteoperosis/Osteopenia } & \multicolumn{2}{|c|}{ Normal } & & & \\
\hline & & $\mathbf{n}$ & $\%$ & n & $\%$ & & & \\
\hline \multirow[t]{2}{*}{ Usia (tahun) } & $\geq 50$ & 13 & 50,0 & 13 & 50,0 & 0,047 & 2,625 & $1,100-6,265$ \\
\hline & $<50$ & 32 & 27,6 & 84 & 72,4 & & & \\
\hline \multirow[t]{2}{*}{ Jenis kelamin } & Wanita & 29 & 30,2 & 67 & 69,8 & 0,722 & 0,812 & $0,385-1,713$ \\
\hline & Pria & 16 & 34,8 & 30 & 65,2 & & & \\
\hline \multirow[t]{2}{*}{ Tempat tinggal } & Urban & 15 & 34,1 & 29 & 65,9 & 0,828 & 1,172 & $0,550-2,500$ \\
\hline & Rural & 30 & 30,6 & 68 & 69,4 & & & \\
\hline \multirow[t]{2}{*}{ Tingkat pendidikan } & Rendah & 29 & 32,2 & 61 & 67,8 & 1,000 & 1,070 & $0,512-2,234$ \\
\hline & Tinggi & 16 & 30,8 & 36 & 69,2 & & & \\
\hline \multirow[t]{2}{*}{ Tingkat pengetahuan } & Kurang & 28 & 34,1 & 54 & 65,9 & 0,580 & 1,312 & $0,636-2,704$ \\
\hline & Baik & 17 & 28,3 & 43 & 71,7 & & & \\
\hline
\end{tabular}


Tabel 3. Hubungan antara Gaya Hidup dengan Gangguan Kepadatan Tulang

\begin{tabular}{|c|c|c|c|c|c|c|c|c|}
\hline \multirow{3}{*}{ Variabel } & \multirow{3}{*}{ Kategori } & \multicolumn{4}{|c|}{ Gangguan Kepadatan Tulang } & \multirow{3}{*}{ Nilai $p$} & \multirow{3}{*}{ OR } & \multirow{3}{*}{$\mathbf{9 5} \% \mathrm{CI}$} \\
\hline & & \multicolumn{2}{|c|}{ Osteoperosis/Osteopenia } & \multicolumn{2}{|c|}{ Normal } & & & \\
\hline & & $\mathbf{n}$ & $\%$ & $\mathbf{n}$ & $\%$ & & & \\
\hline \multirow[t]{2}{*}{ Aktivitas olahraga } & Tidak & 31 & 32,3 & 65 & 67,7 & \multirow[t]{2}{*}{0,976} & \multirow[t]{2}{*}{1,090} & \multirow[t]{2}{*}{$0,510-2,331$} \\
\hline & Ya & 14 & 30,4 & 32 & 69,6 & & & \\
\hline \multirow[t]{2}{*}{ Kebiasaan merokok } & Perokok & 10 & 33,3 & 20 & 66,7 & \multirow[t]{2}{*}{1,000} & \multirow[t]{2}{*}{1,100} & \multirow[t]{2}{*}{$0,466-2,59$} \\
\hline & Dulu dan bukan perokok & 35 & 31,3 & 77 & 68,8 & & & \\
\hline \multirow{2}{*}{$\begin{array}{l}\text { Konsumsi minuman } \\
\text { penghambat penyerapan } \\
\text { kalsium }\end{array}$} & $\geq$ median $(2,0)$ & 23 & 30,3 & 53 & 69,7 & \multirow[t]{2}{*}{0,833} & \multirow[t]{2}{*}{0,868} & \multirow[t]{2}{*}{$0,428-1,762$} \\
\hline & $<$ median $(2,0)$ & 22 & 33,3 & 44 & 66,7 & & & \\
\hline
\end{tabular}

Tabel 4. Hubungan antara Asupan Zat Gizi dengan Gangguan Kepadatan Tulang

\begin{tabular}{|c|c|c|c|c|c|c|c|c|}
\hline \multirow{3}{*}{ Variabel } & \multirow{3}{*}{ Kategori } & \multicolumn{4}{|c|}{ Gangguan Kepadatan Tulang } & \multirow{3}{*}{ Nilai p } & \multirow{3}{*}{ OR } & \multirow{3}{*}{$95 \% \mathrm{CI}$} \\
\hline & & \multicolumn{2}{|c|}{ Osteoperosis/Osteopenia } & \multicolumn{2}{|c|}{ Normal } & & & \\
\hline & & $\mathbf{n}$ & $\%$ & $\mathbf{n}$ & $\%$ & & & \\
\hline \multirow[t]{2}{*}{ Asupan kalsium } & Kurang & 42 & 31,6 & 91 & 68,4 & 1,000 & 0,923 & $0,220-3,870$ \\
\hline & Cukup & 3 & 33,3 & 6 & 66,7 & & & \\
\hline \multirow{2}{*}{ Asupan vitamin D } & Kurang & 36 & 35,6 & 65 & 64,4 & 0,164 & 1,969 & $0,847-4,581$ \\
\hline & Cukup & 9 & 22,0 & 32 & 78,0 & & & \\
\hline \multirow[t]{2}{*}{ Asupan fosfor } & Kurang & 10 & 23,8 & 32 & 76,2 & 0,267 & 0,580 & $0,256-1,318$ \\
\hline & Cukup & 35 & 35,0 & 65 & 65,0 & & & \\
\hline \multirow[t]{2}{*}{ Asupan protein } & Kurang & 15 & 24,2 & 47 & 75,8 & 0,131 & 0,532 & $0,255-1,111$ \\
\hline & Cukup & 30 & 37,5 & 50 & 62,5 & & & \\
\hline
\end{tabular}

Tabel 5. Hubungan antara Indeks Massa Tubuh (IMT) dengan Gangguan Kepadatan Tulang

\begin{tabular}{|c|c|c|c|c|c|c|c|c|}
\hline \multirow{3}{*}{ Variabel } & \multirow{3}{*}{ Kategori } & \multicolumn{4}{|c|}{ Gangguan Kepadatan Tulang } & \multirow{3}{*}{ Nilai p } & \multirow{3}{*}{ OR } & \multirow{3}{*}{$95 \% \mathrm{CI}$} \\
\hline & & \multicolumn{2}{|c|}{ Osteoperosis/Osteopenia } & \multicolumn{2}{|c|}{ Normal } & & & \\
\hline & & $\mathbf{n}$ & $\%$ & $\mathbf{n}$ & $\%$ & & & \\
\hline \multirow[t]{3}{*}{ Indeks massa tubuh $\left(\mathrm{kg} / \mathrm{m}^{2}\right)$} & $<23,49$ & 23,0 & 48,9 & 24,0 & 51,1 & \multirow[t]{3}{*}{0,003} & 4,792 & \multirow{3}{*}{$\begin{array}{l}0,793-5,671 \\
1,852-12,395\end{array}$} \\
\hline & $23,49-27,36$ & 14,0 & 29,8 & 33,0 & 70,2 & & 2,121 & \\
\hline & $>27,36$ & 16,7 & 40,0 & 83,3 & & & & \\
\hline
\end{tabular}

responden yang kurus hanya sedikit $(4,2 \%)$ sehingga tidak dapat dianalisis berdasarkan kategori IMT menurut Kementerian Kesehatan Republik Indonesia tahun 2002. Hasil analisis menunjukkan proporsi gangguan kepadatan tulang menurun seiring dengan peningkatan IMT. Dari hasil uji statistik diperoleh nilai $p=0,003$ sehingga dapat disimpulkan bahwa ada hubungan yang signifikan antara IMT dengan gangguan kepadatan tulang. Berdasarkan nilai OR dapat disimpulkan bahwa responden yang mempunyai IMT $<23,49 \mathrm{~kg} / \mathrm{m}^{2}$ mempunyai peluang 4,7 kali untuk mengalami gangguan kepadatan tulang dibandingkan dengan responden yang mempunyai IMT $>27,36 \mathrm{~kg} / \mathrm{m}^{2}$ dan responden yang mempunyai IMT $23,49-27,36 \mathrm{~kg} / \mathrm{m}^{2}$ mempunyai peluang $2,1 \mathrm{kali}$ untuk mengalami gangguan kepadatan tulang dibandingkan dengan responden yang mempunyai IMT > 27,36 $\mathrm{kg} / \mathrm{m}^{2}$ (Tabel 5).

Berdasarkan hasil analisis multivariat, diperoleh satu variabel yang berhubungan secara signifikan dengan gangguan kepadatan tulang yaitu variabel IMT (nilai $\mathrm{p}<$ 0,05). Sedangkan, variabel usia, asupan vitamin $\mathrm{D}$, dan asupan protein sebagai variabel confounding. Responden yang mempunyai IMT $<23,49 \mathrm{~kg} / \mathrm{m}^{2}$ akan mengalami gangguan kepadatan tulang sebesar 5,5 kali lebih tinggi dibandingkan dengan responden yang mempunyai IMT > $27,36 \mathrm{~kg} / \mathrm{m}^{2}$ dan responden yang mempunyai IMT 23,49 - 27,36 kg/m² akan mengalami gangguan kepadatan tulang sebesar 2,2 kali lebih tinggi dibandingkan dengan responden yang mempunyai IMT $>27,36 \mathrm{~kg} / \mathrm{m}^{2}$ setelah dikontrol variabel usia, asupan vitamin $\mathrm{D}$ dan protein (Tabel 6).

\section{Pembahasan}

Pada penelitian ini, terdapat hubungan yang signifikan antara usia dengan gangguan kepadatan tulang. Dari hasil uji statistik, diperoleh hasil bahwa responden 
Tabel 6. Model Akhir Multivariat

\begin{tabular}{lllll}
\hline Variabel & B & Nilai p & OR & 95\% CI \\
\hline Usia & 0,895 & 0,072 & 2,448 & $0,924-6,488$ \\
Asupan vitamin D & 0,791 & 0,102 & 2,204 & $0,854-5,689$ \\
Asupan protein & $-0,716$ & 0,083 & 0,489 & $0,218-1,097$ \\
IMT (1) & 0,775 & 0,141 & 2,171 & $0,774-6,090$ \\
IMT (2) & 1,696 & 0,001 & 5,454 & $1,987-14,969$ \\
\hline
\end{tabular}

yang berusia $\geq 50$ tahun mempunyai peluang 2,6 kali untuk mengalami gangguan kepadatan tulang dibandingkan dengan responden yang berusia $<50$ tahun. Massa tulang akan semakin berkurang dari waktu ke waktu. Oleh karena itu, risiko terjadinya osteoporosis meningkat seiring dengan pertambahan usia. Setelah melewati puncak pembentukan massa tulang (peak bone mass), tulang akan mengalami penurunan kepadatan mineral tulang. Massa tulang mulai menurun baik pada pria maupun wanita pada awal 30 tahunan dengan sejumlah kecil pengurangan tulang trabekular pada tulang punggung. ${ }^{4-6}$

Hasil penelitian menunjukkan bahwa tidak ada hubungan yang signifikan antara jenis kelamin dengan gangguan kepadatan tulang. Penelitian ini juga menemukan proporsi responden yang mengalami gangguan kepadatan tulang lebih banyak pada pria dibandingkan pada wanita. Hal ini terjadi karena responden wanita lebih banyak berasal dari daerah rural $(78,1 \%)$. Kecenderungan prevalensi gangguan kepadatan tulang pada masyarakat tersebut lebih rendah dibandingkan dengan masyarakat urban jika dikaitkan dengan aktivitas fisik yang lebih tinggi. Mayoritas responden wanita yang bukan perokok $(92,7 \%)$ dapat mencegah kerusakan tulang lebih cepat. Di samping itu, sebagian besar responden wanita masih berusia $<50$ tahun $(86,5 \%)$ yang kebanyakan belum memasuki menopause. Defisiensi estrogen pada wanita menopause memegang peranan penting pada pertumbuhan tulang dan proses penuaan. Penurunan kadar estrogen akan memacu aktivitas pembentukan kembali tulang yang semakin tidak seimbang karena osteoblas tidak dapat mengimbangi kerja osteoklas sehingga massa tulang akan menurun dan mengalami osteoporosis. Aktivitas osteoklas yang meningkat akan menyebabkan terbentuk lacuna Howship yang dalam dan putusnya trabekula sehingga kekuatan tulang akan menjadi turun dan tulang mudah fraktur. Setelah menopause, wanita kehilangan sekitar 2\% dan kadang hingga 5\% massa tulang per tahunnya, selama $4-8$ tahun pertama setelah menopause. Sedangkan saat sebelum menopause, massa tulang berkurang $<1 \%$ per tahunnya. ${ }^{7}$ Osteoporosis pada pria biasanya disebabkan oleh faktor usia yang sudah semakin lanjut sehingga terjadi penurunan massa tulang.

Proporsi responden yang mengalami gangguan kepa- datan tulang ditemukan lebih banyak pada responden yang tinggal di wilayah urban dibandingkan dengan yang tinggal di wilayah rural. Masyarakat urban yang mengalami kemajuan teknologi dan peningkatan penggunaan transportasi baik umum maupun pribadi, dapat menyebabkan pergeseran aktivitas fisik menjadi kurang aktif. ${ }^{8}$ Pustaka lain menambahkan, masyarakat urban dengan segala kemudahannya dalam berbagai fasilitas hidup dapat memberikan kecenderungan pada sedentary lifestyle seperti kurangnya aktivitas olahraga yang menjadi faktor risiko dari osteoporosis dan osteopenia. ${ }^{9}$ Karakteristik responden yang berasal dari daerah rural dalam penelitian ini mayoritas penduduknya mempunyai pekerjaan sebagai buruh, peternak, petani, serta keadaan tempat tinggal yang berjauhan antara satu dengan yang lain. Aktivitas fisik yang memerlukan kekuatan otot dan memberikan pembebanan terhadap tulang ini merupakan faktor protektif dari gangguan kepadatan tulang. Tidak signifikannya hubungan ini dimungkinkan karena jumlah sampel yang kurang, sehingga tidak dapat menunjukkan adanya hubungan yang signifikan antara wilayah tempat tinggal dengan gangguan kepadatan tulang. Penelitian lain yang dilakukan oleh Fatmah, ${ }^{10}$ pada usia lanjut etnis Jawa memperoleh hubungan yang signifikan antara wilayah tempat tinggal dengan kejadian osteoporosis.

Proporsi responden yang mengalami gangguan kepadatan tulang lebih banyak pada mereka dengan tingkat pendidikan rendah dibandingkan dengan yang tingkat pendidikan tinggi. Ada banyak faktor risiko yang dihubungkan dengan kejadian osteoporosis dan osteopenia, seperti rendahnya puncak massa tulang, penggunaan obat-obatan, kebiasaan merokok, aktivitas fisik yang rendah, asupan kalsium dan vitamin D yang kurang, serta IMT yang kurang. Beberapa faktor risiko tersebut diduga lebih umum terjadi pada orang dengan tingkat pendidikan yang rendah. ${ }^{11}$ Tingkat pendidikan dapat memengaruhi kemampuan seseorang dalam menyerap dan menerima informasi kesehatan dan gizi, serta kemampuan berperan serta dalam mewujudkan status kesehatan dan gizi yang baik. Penelitian lain menyimpulkan bahwa tingkat pendidikan yang lebih tinggi secara independen berkaitan dengan DMT yang lebih baik dan prevalensi osteoporosis yang lebih rendah pada wanita postmenopause di Cina. ${ }^{12}$

Proporsi responden yang mengalami gangguan kepadatan tulang lebih banyak yang mempunyai tingkat pengetahuan kurang dibandingkan dengan yang tingkat pengetahuan baik. Pengetahuan merupakan salah satu faktor predisposisi yang memengaruhi perilaku seseorang. Faktor perilaku, lingkungan, genetik, dan pelayanan kesehatan berhubungan secara langsung terhadap status kesehatan seseorang. Pengetahuan tentang gizi memengaruhi seseorang dalam memilih bahan makanan untuk dikonsumsi. Dengan pendidikan dan pengetahuan 
yang baik, faktor-faktor risiko osteoporosis dan osteopenia dapat dihindari dengan informasi yang tepat. ${ }^{13}$ Tidak signifikannya hubungan ini mungkin terjadi karena jumlah sampel yang kurang sehingga tidak dapat menunjukkan adanya hubungan yang signifikan antara tingkat pengetahuan dengan gangguan kepadatan tulang.

Proporsi responden yang mengalami gangguan kepadatan tulang lebih banyak yang tidak berolahraga dibandingkan dengan yang berolahraga. Tulang memerlukan tekanan dari olahraga agar proses pembentukan tulang sebanding dengan pengikisan tulang. ${ }^{14}$ Olahraga sederhana seperti berjalan dapat membantu memperkuat tulang dan otot. Olahraga yang bersifat resistance training dan weight bearing exercise cenderung lebih bermanfaat karena dapat membantu membangun tulang dan mempertahankan massa tulang. Termasuk di dalamnya angkat beban, hiking, menaiki tangga, aerobik, menari, dan olahraga lainnya yang memerlukan otot bekerja melawan gravitasi. Olahraga juga bermanfaat untuk meningkatkan keseimbangan tubuh sehingga terhindar dari jatuh. ${ }^{15}$

Proporsi responden yang mengalami gangguan kepadatan tulang ditemukan lebih banyak yang perokok dibandingkan dengan yang dahulu perokok dan bukan perokok. Tidak signifikannya hubungan ini dimungkinkan karena jumlah sampel yang tidak terlalu banyak sehingga tidak dapat menunjukkan adanya hubungan yang signifikan antara tingkat kebiasaan merokok dengan gangguan kepadatan tulang. Kebiasaan merokok dapat melipat gandakan risiko terjadinya osteoporosis. Kandungan nikotin dalam rokok akan menghambat sekresi estrogen, merangsang kerusakan estrogen dalam hati dan mempercepat terjadinya menopause. Merokok juga akan mengacaukan efek protektif kalsium pada tulang karena kandungan logam berat rokok, seperti kadmium, timbal, dan yang lainnya, akan mengganggu penyerapan kalsium dalam usus. Di samping itu, merokok akan menghambat kerja dari osteoblas dan menghilangkannya dari peredaran darah. ${ }^{16}$ Pustaka lain menambahkan, wanita perokok akan memasuki masa menopause $1-2$ tahun lebih cepat dibandingkan dengan wanita bukan perokok. Selain itu, pada wanita yang merokok satu bungkus per hari selama masa dewasanya, mempunyai DMT 5 - 10\% lebih rendah pada saat usia menopause dibandingkan dengan wanita yang tidak merokok. ${ }^{17}$

Hasil penelitian ini menunjukkan hubungan yang tidak signifikan antara kebiasaan konsumsi minuman penghambat penyerapan kalsium dengan gangguan kepadatan tulang. Dalam pengumpulan data primer, digunakan FFQ untuk mengetahui frekuensi konsumsi minuman penghambat penyerapan kalsium (kopi, teh, dan minuman ringan) dalam satuan hari, minggu, dan bulan. Oleh karena itu, recall bias sangat mungkin terjadi pada responden dalam menentukan frekuensi konsumsi kopi, teh, dan minuman ringan yang sebenarnya. Kafein dalam menyebabkan terjadinya osteoporosis dikaitkan dengan penggantian susu dari diet, penghambatan absorpsi kalsium dalam usus dan peningkatan ekskresi kalsium melalui urin. ${ }^{18}$ Kafein bertindak sebagai diuretik yang menyebabkan peningkatan ekskresi dari kalsium dan magnesium. Di samping itu, kandungan asam fosfat yang tinggi dalam minuman ringan akan mengikat kalsium dalam usus sehingga menurunkan absorpsi kalsium. Keadaan ini akan berdampak pada ketidakseimbangan kalsium dan peningkatan kehilangan kalsium. Ditambah lagi, kebanyakan minuman ringan juga mengandung kafein yang telah diidentifikasi sebagai salah satu faktor risiko osteoporosis dan osteopenia. ${ }^{19}$

Dalam penelitian ini, didapatkan hubungan yang tidak signifikan antara asupan kalsium dengan gangguan kepadatan tulang. Hal ini dapat terjadi akibat terlalu sedikitnya responden yang mempunyai asupan kalsium yang cukup $(6,3 \%)$. Sementara Angka Kecukupan Gizi $(\mathrm{AKG})$ kalsium yang dianjurkan bagi orang Indonesia untuk kelompok usia 30 - 49 tahun dan 50-64 tahun, baik bagi pria maupun wanita adalah $800 \mathrm{mg}$ per hari. Rendahnya asupan kalsium responden ini karena sangat sedikitnya responden yang mengonsumsi sumber makanan berkalsium tinggi seperti susu dan produk olahannya. Sebagian besar responden dalam penelitian ini berasal dari daerah rural dan memiliki tingkat ekonomi dan pendidikan yang rendah. Hal ini dapat memengaruhi pemilihan jenis makanan dengan kandungan gizi yang tidak seimbang. Asupan kalsium yang optimal diperlukan untuk memaksimalkan massa puncak dan mempertahankan massa tulang pada usia dewasa serta meminimalkan kehilangan massa tulang pada usia lebih lanjut. Rendahnya asupan kalsium berdampak pada pengeroposan tulang karena akan menstimulasi hormon paratiroid untuk melepas cadangan kalsium dalam tulang. ${ }^{20}$

Hasil yang diperoleh dalam penelitian ini menunjukkan tidak ada hubungan yang signifikan antara asupan vitamin D dengan gangguan kepadatan tulang. Namun, proporsi responden yang mengalami gangguan kepadatan tulang ditemukan lebih banyak pada responden yang asupan vitamin D kurang dibandingkan dengan yang asupan vitamin D cukup. Vitamin D berperan penting dalam menjaga homeostasis kalsium dengan cara meningkatkan absorpsi kalsium di usus dan mobilisasi kalsium dari tulang pada keadaan asupan kalsium yang inadekuat. Jumlah vitamin D yang adekuat sangat penting untuk menjaga keseimbangan kalsium dan merupakan faktor protektif dari terjadinya osteoporosis dan osteopenia. Pada analisis multivariat, terbukti bahwa asupan vitamin D merupakan variabel confounder. Setelah dilakukan tabulasi silang antara variabel asupan vitamin $\mathrm{D}$ dengan beberapa variabel independen lainnya diketahui bahwa proporsi responden yang asupan vitamin D cukup, banyak yang 
tidak melakukan aktivitas olahraga dan mempunyai kebiasaan konsumsi minuman penghambat penyerapan kalsium $\geq$ median. Hal ini akan memberikan efek yang negatif terhadap tulang.

Dalam penelitian ini, tidak didapatkan hubungan yang signifikan antara asupan fosfor dengan gangguan kepadatan tulang. Hubungan ini dapat disebabkan oleh recall bias yang terjadi pada responden dalam mengingat apa yang dikonsumsi selama 24 jam dan jumlah yang dikonsumsi. Selain itu, food recall 24 jam dalam penggunaannya, memungkinkan responden untuk memberikan informasi yang bukan sebenarnya tentang apa yang dikonsumsi. Fosfor merupakan unsur pembentuk tulang yang penting. Seperti kalsium, pasokan yang cukup dari fosfor untuk tulang diperlukan sepanjang hidup. Baik kalsium maupun fosfor diperlukan untuk kecukupan mineralisasi kerangka. Penurunan fosfat serum akan menyebabkan gangguan mineralisasi tulang dan fungsi osteoblas. Sebanyak $85 \%$ fosfor ditemukan bersama kalsium dalam bentuk kristal hidroksiapatit pada tulang. ${ }^{21}$

Hasil yang diperoleh dalam penelitian ini menunjukkan tidak ada hubungan yang signifikan antara asupan protein dengan gangguan kepadatan tulang. Asupan protein memberi pengaruh terhadap pertumbuhan tulang pada usia kanak-kanak dan risiko fraktur di usia yang lebih lanjut. Kecukupan asupan protein pada masa kanakkanak sangat diperlukan untuk sintesis osteoid (matriks tulang). Pada orang-orang yang mengalami malnutrisi kronis, terdapat kecenderungan tulang untuk menjadi lebih tipis pada penampangnya. Beberapa studi menunjukkan bahwa pada mereka yang mengonsumsi terlalu sedikit protein menyebabkan tulang menjadi lemah. Selain itu, pada penderita patah tulang panggul yang tidak mendapatkan cukup protein cenderung mempunyai pemulihan yang lambat. ${ }^{22}$ Analisis multivariat pada penelitian ini menunjukkan bahwa asupan protein merupakan variabel confounder. Proporsi responden yang mengalami gangguan kepadatan tulang lebih banyak pada mereka yang asupan proteinnya cukup dibandingkan yang asupan proteinnya kurang (faktor protektif). Dalam pustaka dijelaskan bahwa konsumsi protein yang terlalu tinggi dapat membahayakan tulang. Suasana asam yang dihasilkan selama proses metabolisme dan pemecahan protein, harus terlebih dahulu dinetralisir dengan kalsium sebelum dieliminasi oleh ginjal. Asam amino metionin yang paling banyak ditemukan dalam sumber protein hewani (daging sapi, telur) diubah menjadi homosistein juga menyebabkan hilangnya tulang. Apabila asupan tinggi protein tidak diimbangi dengan asupan tinggi kalsium, akan terjadi keseimbangan kalsium negatif sehingga membutuhkan kalsium dari tulang. ${ }^{23,24}$

Pada penelitian ini, diperoleh proporsi gangguan kepadatan tulang menurun seiring dengan peningkatan IMT. Hasil analisis multivariat menunjukkan bahwa IMT merupakan faktor yang paling berhubungan dengan gangguan kepadatan tulang setelah dikontrol dengan variabel usia, asupan vitamin $\mathrm{D}$, dan asupan protein. Di mana responden yang mempunyai IMT $<23,49 \mathrm{~kg} / \mathrm{m}^{2}$ akan mengalami gangguan kepadatan tulang sebesar 5,5 kali lebih tinggi dibandingkan dengan responden yang mempunyai IMT $>27,36 \mathrm{~kg} / \mathrm{m}^{2}$ dan responden yang mempunyai IMT $23,49-27,36 \mathrm{~kg} / \mathrm{m}^{2}$ akan mengalami gangguan kepadatan tulang sebesar 2,2 kali lebih tinggi dibandingkan dengan responden yang mempunyai IMT > $27,36 \mathrm{~kg} / \mathrm{m}^{2}$ setelah dikontrol variabel usia, asupan vitamin D, dan asupan protein. Dalam sebuah pustaka dijelaskan, individu dengan IMT rendah mengakibatkan penurunan beban mekanik tulang yang dapat merangsang penurunan kepadatan tulang seseorang. Sementara itu, orang yang mempunyai berat badan lebih menunjukkan efek protektif terhadap tulang. Tekanan yang besar pada tulang orang overweight merangsang pembentukan tulang baru. Selain itu, pada orang overweight juga mempunyai jaringan lemak yang banyak sehingga menghasilkan produksi estrogen yang lebih banyak. Estrogen ini merupakan hormon yang berperan penting dalam mempertahankan kepadatan tulang seseorang, khususnya wanita. ${ }^{2}$

\section{Kesimpulan}

Proporsi gangguan kepadatan tulang kelompok usia dewasa di daerah urban dan rural Provinsi Jawa Barat sebesar $31,7 \%$ (4,2\% osteoporosis dan $27,5 \%$ osteopenia). Proporsi gangguan kepadatan tulang lebih banyak pada mereka yang tinggal di daerah urban, mempunyai tingkat pendidikan dan pengetahuan yang rendah, tidak melakukan aktivitas olahraga, merokok, dan asupan vitamin D yang kurang. Usia dan IMT secara signifikan berhubungan dengan gangguan kepadatan tulang.

\section{Saran}

Pihak puskesmas agar membuat program pencegahan gangguan kepadatan tulang melalui promosi dan penyuluhan kepada masyarakat tentang gangguan kepadatan tulang itu sendiri dan pentingnya konsumsi makanan bergizi dan seimbang. Masyarakat disarankan untuk membiasakan berolahraga secara rutin ( 3 - 5 kali per minggu dengan durasi minimal 30 menit setiap kali berolahraga) dan menghindari kebiasaan merokok untuk menjaga kesehatan tulang sehingga terhindar dari gangguan kepadatan tulang. Akademisi disarankan untuk dapat mengembangkan penelitian ini lebih lanjut dengan desain yang berbeda seperti kontrol kasus ataupun kohort dan jumlah sampel yang lebih besar.

\section{Daftar Pustaka}

1. WHO. Assessment of fracture risk and its application to screening for postmenopausal osteoporosis. WHO Technical Report Series. Geneva: 
WHO; 1994.

2. Bartl R, Frisch B. Osteoporosis diagnosis, prevention, therapy. 2nd ed. Berlin: Springer; 2009.

3. Jahari AB, Prihatini S. Faktor determinan risiko osteoporosis di tiga provinsi di Indonesia. Media Litbang Kesehatan. 2010; 20 (2): 91-9.

4. Grosvenor BM, Smolin LA. Nutrition from science to life. Philadelphia: Elsevier; 2002.

5. Stevenson JC, Marsh MS. An atlas of osteoporosis. 3rd edition. London: Informa Healthcare; 2007.

6. Lane NE. Lebih lengkap tentang: osteoporosis rapuh tulang. Jakarta: PT RajaGrafindo Persada; 2001.

7. Sudoyo AW, Setiyodi B, Alwi I, Simadibrata M, Setiati S, et al. Buku Ajar Ilmu Penyakit Dalam. Jakarta: Departemen Ilmu Penyakit Dalam FK UI; 2006.

8. Ruel MT, Haddad L, Garret JL. Some urban of life: implications for research and policy. Washington DC: Food Consumption and Nutrition Division International Food Policy Research Institute; 1999.

9. Shehu RA, Abdullahi AA, Adekeye DS. Sedentary lifestyle and wellness in Kaduna State, Nigeria. Ethnomed. 2010; 4 (1): 15-9.

10. Fatmah. Osteoporosis dan faktor risikonya pada lansia Etnis Jawa. Media Medika Indonesiana. 2008; 43 (2): 54-64.

11. Maddah M, Sharami SH, Karandish M. Educational difference in the prevalence of osteoporosis in postmenopausal women: a study in Northern Iran. BMC Public Health. 2011; 11: 845.

12. Ho SC, Chen Y, Woo JLF. Osteoporosis risk in postmenopausal Chinese Woman. American Journal of Epidemiology. 2005; 161: 680-90.

13. Notoatmodjo S. Pendidikan dan ilmu perilaku kesehatan. Jakarta: Rineka Cipta; 2003.
14. Alexander IM, Knight KA. Questions and answers about osteoporosis and osteopenia. 2nd ed. Sudbury: Jones and Bartlett Publishers; 2010

15. Chan KM, Anderson M, Lau EMC. Exercise intervention: defusing the world's osteoporosis time bomb. Bulletin of the World Health Organization. 2003; 81 (11): 827-30.

16. Compston J. Seri kesehatan bimbingan dokter pada osteoporosis. Jakarta: Dian Rakyat; 2002.

17. Keramat A, Patwardhan B, Larijani B, Chopra A, Mithal A, Chakravarty $\mathrm{D}$, Adibi $\mathrm{H}$. The assessment of osteoporosis risk factors in Iranian women compared with Indian women. BMC Musculoskeletal Disorders. 2008; 9: 28 .

18. Wetmore CM, Ichikawa L, LaCroix AZ, Ott Sm, Scholes D. Association between caffeine intake and bone mass among young women: potential effect modification by depot medroxyprogesterone acetate use. Osteoporosis International. 2008; 19: 519-27.

19. Tucker KL, Morita K, Qiao N, Hannan MT, Cupples A, Kiel DP. Colas, but not other carbonated beverages, are associated with low bone mineral density in older women: the Framingham osteoporosis study. American Journal of Clinical Nutrition. 2006; 84: 936-42.

20. Adler RA. Osteoporosis pathophysiology and clinical management. $2^{\text {nd }}$ edition. New York: Humana Press; 2010.

21. Prentice A. Diet, nutrition and the prevention of osteoporosis. Public Health Nutrition. 2004; 7 (1A): 227-43.

22. O'Connor CR, Perkins S. Osteoporosis for dummies. Canada: Wiley Publ Inc; 2005.

23. Fatmah. Gizi usia lanjut. Jakarta: Erlangga; 2010.

24. Stransky M, Rysava L. Nutrition as prevention and treatment of osteoporosis. Physiological Research. 2009; 58 (suppl 1): 680-90. 